\title{
Nonstoichiometry and Phase Stability of Spinel Ferrite $\left(\mathrm{Mg}_{x} \mathrm{Fe}_{1-x}\right)_{3-\delta} \mathrm{O}_{4}$
}

\author{
S.-H. Kang and H.-I. Yoo \\ Solid State Ionics Research Lab., School of Materials Science and Engineering, Seoul National \\ University, Seoul 151-742, Korea
}

\begin{abstract}
The nonstoichiometry $(\delta)$ and phase stability range of $\left(\mathrm{Mg}_{x} \mathrm{Fe} \mathrm{e}_{1-x}\right)_{3-\delta} \mathrm{O}_{4}$ has been determined by a coulometric titration method as a function of oxygen activity and the $\mathrm{Mg}$ content $(\mathrm{x})$ at $1000^{\circ} \mathrm{C}$. The nonstoichiometry can best be explained in terms of Frenkel disorder.
\end{abstract}

\section{INTRODUCTION}

The electrical and magnetic properties of a ferrite depends, for a given cationic composition, on the oxidation states of transition metal ions therein, which are closely related to the oxygen nonstoichiometry. Furthermore, a close control of the oxygen activity in the surrounding is critical to prevent undesirable precipitation of a second phase in the ferrite during sintering or cooling. The information on the nonstoichiometry and phase stability of the ferrite is, therefore, essential to tailoring the optimum properties of the ferrite.

In this work, we determine in situ by solid-state coulometric titration the nonstoichiometry $(\delta)$ and phase stability range of $\mathrm{Mg}$-ferrous ferrite, $\left(\mathrm{Mg}_{x} \mathrm{Fe}_{1-\mathrm{x}}\right)_{3-\delta} \mathrm{O}_{4}$ against oxygen partial pressure ( $\mathrm{PO2}$ ) and the $\mathrm{Mg}$ content $(\mathrm{x})$ at $1000^{\circ} \mathrm{C}$.

\section{EXPERIMENTAL}

The ferrite samples $\left(\mathrm{Mg}_{x} \mathrm{Fe}_{1-\mathrm{x}}\right)_{3-\delta} \mathrm{O}_{4}$ of $\mathrm{x}=0.29,0.24$, and 0.15 , respectively, were prepared via a conventional ceramic processing route. Coulometric titration was carried out with the cell, $\mathrm{Pt},\left(\mathrm{Mg}_{\mathrm{x}} \mathrm{Fe}_{1-x}\right)_{3-}$ ${ }_{\delta} \mathrm{O}_{4}\left|\mathrm{ZrO}_{2}\left(+8 \mathrm{~m} / 0 \quad \mathrm{Y}_{2} \mathrm{O}_{3}\right)\right| \mathrm{Pt}$, $\mathrm{PO}_{2}{ }^{\text {(ref) }}$. The experimental details are referred to Ref. 2 .

\section{RESULTS AND DISCUSSION}

Figure 1 shows the result, $\delta(\mathrm{Poz})$ at $1000^{\circ} \mathrm{C}$. The nonstoichiometry appears to vary sine-hyperbolically against oxygen partial pressure, exhibiting a strong dependence on the $\mathrm{Mg}^{-}$-content, $\mathrm{x}$.

Magnetite $\left(\mathrm{Fe}_{3-\delta} \mathrm{O}_{4}\right)$ and mixed spinels thereof are known to have the Frenkel disorder, i.e., cation vacancies in the high $\mathrm{Po}_{2}$ region and cation interstitials in the low $\mathrm{PO}_{2}$ region[3-5]. $\left(\mathrm{Mg}_{\mathrm{x}} \mathrm{Fe}_{1-\mathrm{x}}\right)_{3-\delta} \mathrm{O}_{4}$ is also highly likely to have the same defect structure. At a given temperature, the nonstoichiometry of $\left(\mathrm{Mg}_{\mathrm{x}} \mathrm{Fe}_{1-\mathrm{x}}\right)_{3-\hat{\delta}} \mathrm{O}_{4}$ spinel can, thus, be best represented as[3]

$$
\delta=[\mathrm{l}]^{\circ} \cdot\left(\mathrm{PO}_{2} / \mathrm{atm}\right)^{2 / 3}-[\mathrm{I}]^{\circ} \cdot\left(\mathrm{Po}_{2} / \mathrm{atm}\right)^{-2 / 3}
$$

where $[\mathrm{V}]^{\circ}$ and $[\mathrm{I}]^{\circ}$ are the concentration of cation vacancies and interstitials corresponding to $\mathrm{PO}_{2}=1 \mathrm{~atm}$, respectively. 
As the $\mathrm{Mg}$ content, $\mathrm{x}$, increases from 0 to 0.29 , the titration curves shift towards higher oxygen potential, indicating that increasing $x$ reduces $[V]^{\circ}$ and enhances $[\mathrm{I}]^{\circ}$. Actually, values for $[\mathrm{V}]^{\circ}$ and $[\mathrm{I}]^{\circ}$ change by 2-3 orders of magnitude. Such a marked change over an $\mathrm{Mg}$-content change of $\mathrm{x}=0$ to 0.29 may be attributed to the fact that $\mathrm{Mg}$ remains fixed-valent (i.e., $\mathrm{Mg}^{2+}$ ) in the ferrite and hence, increasing amount of $\mathrm{Mg}$ reduces the oxidation capacity of the ferrite. Similar results have also been reported for $(\mathrm{Co}, \mathrm{Fe})_{3-} \delta$ $\mathrm{O}_{4}$ spinel[5], in which $\mathrm{Co}$ is known to exist exclusively as $\mathrm{Co}^{2+}$.

When a second phase such as hematite or wüstite forms in an otherwise homogeneous ferrite spinel, the trend of $\delta$-variation is expected to deviate from Eq. (1) due to the reduction of thermodynamic degrees of freedom. The phase boundaries of a ferrite, therefore, can be assigned to the point where a titration curve starts to deviate. Figure 2 shows the stability range of $\left(\mathrm{Mg}_{0.15} \mathrm{Fe}_{0.85}\right)_{3-\delta} \mathrm{O}_{4}$ determined thereby, which is in good agreement with the reported [6,7].

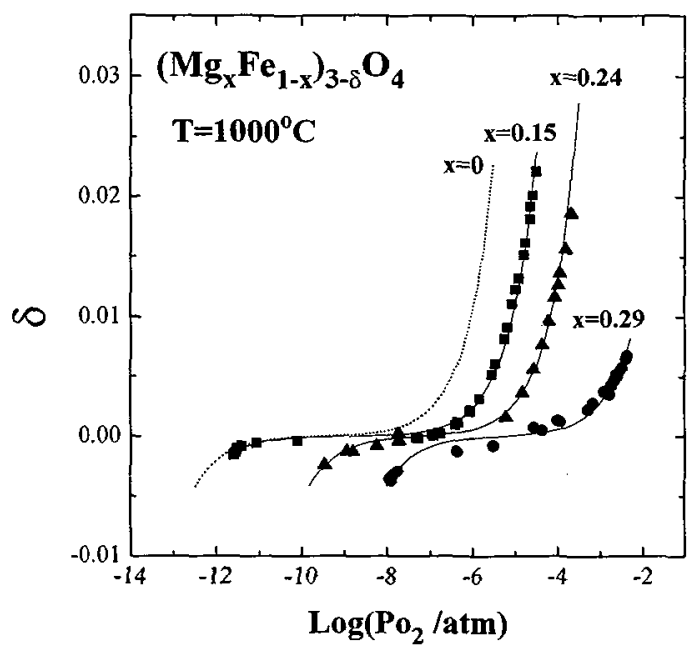

Fig. 1. Nonstoichiometry, $\delta$, of $\left(\mathrm{Mg}_{x} \mathrm{Fe}_{1-x}\right)_{3-\delta} \mathrm{O}_{4}$ vs. oxygen partial pressure, $\mathrm{PO}_{2}$, at $1000^{\circ} \mathrm{C}$ for different compositions. The solid lines are the best fitted to Eq. (1) in the text and the curve for $x=0$ (magnetite) is from Dieckmann[3].

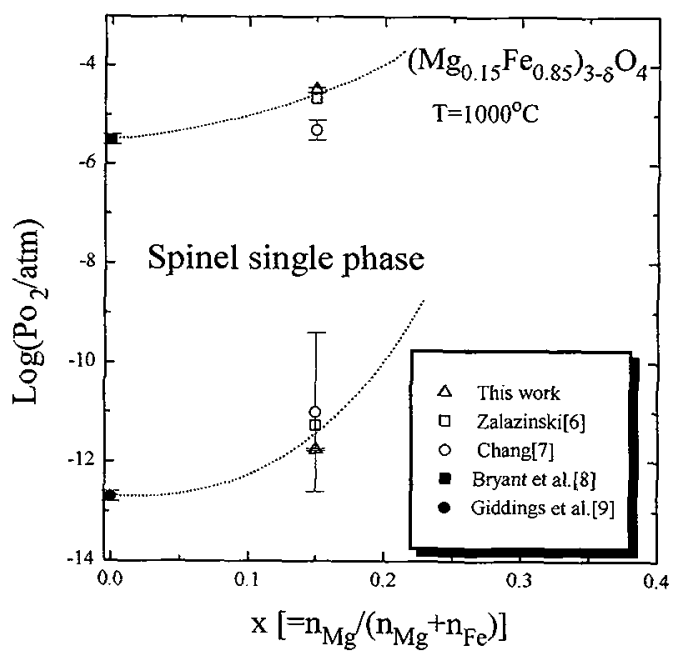

Fig. 2. Phase stability diagram for $\left(\mathrm{Mg}_{0.15} \mathrm{Fe} \mathrm{e}_{85}\right)_{3-\delta} \mathrm{O}_{4}$ spinel at $1000^{\circ} \mathrm{C}$ as a function of oxygen partial pressure $\left(\mathrm{PO}_{2}\right)$. Solid lines are visual guidance only.

Acknowledgement: This work was supported by the Ministry of Education Fund for Advanced Materials 95.

\section{References}

[1] J. Nicolas, in Ferromagnetic materials, Vol.2, (North-Holand Publishing Co., New York, 1980) pp.243-296.

[2] S. -H. Kang and H. -I. Yoo, Solid State Ionics, in press.

[3] R. Dieckmann, Ber. Bunsenges. Phys. Chem. 86 (1982) 112.

[4] F. - H. Lu and R. Dieckmann, Solid State Ionics 59 (1993) 71.

[5] F. -H. Lu, S. Tinkler and R. Dieckmann, Solid State Ionics 62 (1993) 39.

[6] A. G. Zalazinskii et al., Russ. J. Phys. Chem. 49 (1975) 914

[7] S. -H. Chang, Ph.D. thesis, Seoul National University (1993).

[8] P. E. C. Bryant and W. W. Smeltzer, J. Electrochem. Soc. 116 (1969) 1409.

[9] R. A. Giddings and R. S. Gordon, J. Am. Ceram. Soc. 56 (1973) 111. 